\author{
Berdibayeva S.K. ${ }^{1}$, Mayemirov A.M. ${ }^{2}$, Garber A.I. ${ }^{3}$, \\ Sakhiyeva F.A. ${ }^{4}$, Utebayeva A.T. ${ }^{5}$, Berdibayev S.K. ${ }^{6}$ \\ ${ }^{1}$ Doctor of psychological science, Professor, \\ Al-Farabi Kazakh National University, Kazakhstan, Almaty, e-mail: berdybaeva_sveta@mail.ru \\ ${ }^{2}$ Dr. Ph.D, Professor, T. Zhurgenov Kazakh National Academy of Arts, \\ Kazakhstan, Almaty, e-mail: askhatmaemirov@mail.ru \\ ${ }^{3}$ Prof., Dr. Ph.D, Professor, Rehabilitation Clinic «Reinhardshöhe», \\ Germany, Hessen, e-mail: alena.garber@gmx.de \\ ${ }^{4}$ Dr. Ph.D, Associate professor. M. Auezov South Kazakhstan State University, \\ Kazakhstan, Shymkent, e-mail: farida777-84@mail.ru \\ ${ }^{5}$ Senior Lecturer, International Humanitarian and Technical University, \\ Kazakhstan, Shymkent, e-mail: zav_alia@mail.ru \\ ${ }^{6}$ Senior Lecturer, L.N. Gumilyov Eurasian University, \\ Kazakhstan, Nur-Sultan, e-mail: catok-s67@mai.ru

\section{THE PSYCHOLOGICAL PROBLEMS OF TEENAGERS WITH ADDICTIVE BEHAVIOUR: THE ROLE OF LIFE MEANING STRATEGIES}

There are various forms of addictions that teenagers indulge in. Teenage years is a stage in life that when physical and hormonal changes influence a person's field of decision-making. During this time, teenagers are enticed to experiment on drugs and other dangerous habits. Results suggest that attention should be paid to how teenagers are thinking about their futures due to the associated links with long-term social and health behaviours. Overall, this study shows that there are considerable differences both in terms of individual indicators, and on the relationships between the meaning-life orientations and value orientations in the structure of personal life plans of teenagers with addictive behaviour and teenagers that are not prone to addiction.

This result may indicate that the psychological aspects of personal life plans for teenagers influence the development of addictive behaviours. The values of communication: courage in defending one's opinion, honesty, and advertence are more important for teenagers of the control group than for teenagers with addictive behaviour. In the meaning-life orientations and values of a teenager who is not prone to addictive behaviour, the central place is occupied by a strong will as a value - a means of achieving goal, on the second place it is possible to highlight by importance of interrelations the instrumental value - responsibility.

The results of the study can be further used to carry out effective preventive and psycho-corrective work with teenagers. The carried out research has shown that psycho-corrective work should be built with taking into account the formation of personal life plans of teenagers. Identified characteristics of personal life plans for teenagers who are prone to addictive behaviour can be used for psycho diagnostic purposes when carrying out complex judicial psycho-psychiatric examination or forensic psychiatric examination.

Key words: addictive behaviour, life-meaning orientations, values. 


\section{Бердібаева С.Қ. ${ }^{1}$, Маемиров А.М. ${ }^{2}$, Гарбер А.И. ${ }^{3}$,

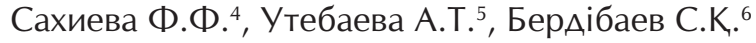 \\ 'психология ғылымдарының докторы, профессор, әл-Фараби атындағы Қазақ, ұлттық университеті, Қазақстан, Алматы қ., е-mail: berdibayeva.sveta@gmail.com ${ }^{2}$ Phd докторы, профессор, Т. Жүргенов атындағы Қазақ ұлттық өнер академиясы, Қазақстан, Алматы қ., e-mail: askhatmaemirov@mail.ru \\ 3Phd докторы, профессор, «Reinhardshöhе« Сауықтырушы клиникасы, Германия, Гессен к., e-mail: alena.garber@gmx.de \\ ${ }^{4} \mathrm{Phd}$ докторы, ассоциативті профессор, М. Әуезов атындағы \\ Оңтүстік Мемлекеттік Университеті, Қазақстан, Шымкент қ., e-mail: farida777-84@mail.ru ${ }^{5}$ аға оқытушы, Халықаралық гуманитарлық-техникалық, университеті, Қазақстан, Шымкент қ., e-mail: zav_alia@mail.ru \\ ${ }^{6}$ аға оқытушы, А.Н. Гумилев атындағы Еуразия ұлттық университеті, Қазақстан, Нұр-Сұлтан қ., e-mail:catok-s67@mai.ru \\ ААдиктивті мінез-құлықты жеткіншектердің психологиялық мәселелері: өмір мағынасындағы стратегияның рөлі}

Жеткіншектер бейім болатын тәуелділіктердің әртүрлі формалары бар. ААамның шешім қабылдауына физикалық және гармондық өзгерістердің әсер ететін бір өмірлік сатысы - ол жеткіншек жасы. Осы кезеңде жеткіншектер наркотиктерге және басқа да қауыпты әдеттерге қатты қызығып, соларды байқап көруге әуес болып тұрады. Зерттеу нәтижелері көрсеткендей, мінез-құлықтың ұзаққа созылатын әлеуметтік және медициналық модельдеріне байланысты жеткіншектердің өздерінің болашақтары туралы не ойлайтындарына көңіл бөлу керек. Жалпы алғанда, зерттеулер келесі жағдайларды көрсетеді, тәуелділікке бейім емес және бейім жеткіншектердің өмірлік жеке бастық жоспарларының құрылымында құндылықтарға бағдарлану мен өмірлік-мағыналық бағдарланулары арасында өте үлкен айырмашылықты көруге болады екен. Бұл нәтижелер мына жағдайларды анықтайды, жеткіншектердің жеке өмірлік жоспарларының психологиялық аспектілері, олардың аАликтивті мінез-құлықтарын дамытуға әсер етеАі. Өз пікірін қорғаудағы мықтылық, адалдық және сақ, болу сияқты қарым-қатынастағы құндылықтар, тәуелді мінез-құлықты жеткіншектерге қарағанда тексеру тобындағы жеткіншектер үшін маңызды. ААликтивті мінез-құлыққа бейім емес жеткіншектерде құндылықтар мен өмірлікмағыналық бағдарлануларында негізгі орынды күшті ерік-жігер, мақсатқа жету тәріздес құндылықтарды бірінші орынға қояды, ал екінші орынға инструменталды құндылық болып табылатын жауапкершілікті маңызды деп санайды. Зерттеу нәтижелерін жеткіншектермен тиімді психокоррекциялық және профилактикалық жұмыстарды жүргізуде қолдануға болады. Жүргізілген зерттеу келесі жағдайларды анықтаАы, психокоррекциялық жұмыстар жеткіншектердің жеке бастық өмірлік жоспарларын ескеріп жүргізілуі керек. ААликтивті мінезқұлыққа бейім жеткіншектер үшін жеке өмірлік жоспарлардың зерттеу барысында анықталған сипаттамаларын сот-психиатриялық сараптамада немесе кешенді соттық психиатриялық, тексерулерде психодиагностикалық мақсатпен қолдануға болады.

Түйін сөздер: аддиктивті мінез-құлық, өмірлік бағдарланулар, құндылықтар.

Бердибаева С.К. ${ }^{1}$, Маемиров А.М. ${ }^{2}$, Гарбер А.И. ${ }^{3}$, Сахиева Ф.Ф. ${ }^{4}$, Утебаева А.Т. ${ }^{5}$, Бердибаев С.К. ${ }^{6}$

${ }^{1}$ Аоктор психологических наук, профессор, Казахский национальный университет имени аль-Фараби, Казахстан, г. Алматы, e-mail: berdibayeva.sveta@gmail.com

${ }^{2}$ Аоктор PhD, профессор, Казахская национальная академия искусств имени Т. Жургенова, Казахстан, г. Алматы, e-mail: askhatmaemirov@mail.ru

${ }^{3}$ Аоктор PhD, профессор, Реабилитационная клиника "Reinhardshöhe", Германия, г. Гессен, e-mail: alena.garber@gmx.de

${ }^{4}$ Аоктор PhD, ассоциированный профессор, Южно-Казахстанский государственный университет

имени М. Ауэзова, Казахстан, г. Шымкент, e-mail: farida777-84@mail.ru

${ }^{5}$ старший преподаватель, Международный гуманитарно-технический университет, Казахстан, г. Шымкент, e-mail: zav_alia@mail.ru

${ }^{6}$ старший преподаватель, Евразийский национальный университет

имени А.Н. Гумилева, Казахстан, г. Нур-Султан, e-mail: catok-s67@mai.ru

\section{Психологические проблемы подростков с адАиктивным поведением: роль стратегий значения жизни}

Существуют различные формы зависимостей, которым подвержены подростки. Подростковые годы - это этап в жизни, когАа физические и гормональные изменения влияют на область принятия решений человеком. В это время подростки соблазняются и экспериментируют наркотиками и другими опасными привычками. Результаты показывают, что следует обратить 
The psychological problems of teenagers with addictive behaviour: the role of life meaning strategies

внимание на то, что подростки Аумают о своем будущем. В целом, это исследование показывает, что существуют значительные различия как с точки зрения индивидуальных показателей, так и с точки зрения смысло-жизненных и ценностных ориентаций в структуре ^ичных жизненных планов подростков с зависимым поведением и подростков, не ск^онных к зависимому поведению.

Этот результат может указывать на то, что психологические аспекты кичных жизненных планов подростков влияют на развитие адликтивного поведения. Ценности общения: мужество в защите своего мнения, честность и осторожность важнее Аля подростков контрольной группы, чем для подростков с зависимым поведением. В смыслово-жизненных ориентациях и ценностях подростка, не склонного к аАдиктивному поведению, центральное место занимает сильная воля как ценность - средство достижения цели, на втором месте можно выделить важность взаимосвязи инструментальнной ценности и ответственности.

Результаты исследования могут быть в дальнейшем использоваться в проведении эффективной профилактической и психокоррекционной работы с подростками. Проведенное исследование показало, что психокоррекционная работа Аолжна строиться с учетом формирования мичных жизненных планов подростков. Выявленные характеристики кичных жизненных планов Аля подростков, скАонных к аААиктивному повеАению, могут использоваться в целях психодиагностики при проведении комплексного судебного, психопсихиатрического обследования или судебно-психиатрической экспертизы.

Ключевые слова: аддиктивное поведение, жизненные ориентации, ценности.

\section{Introduction}

There are a significant number of scientific papers devoted to the issue of constructing life plans. Individual biographies and personal life paths were the subject of analysis in many works (Golovaha \& Kronik, 2014; Kronik \&Ahmerov, 2015; Ahmerov, 2013).

The Leningrad school of psychology created the new term «the personal life path» (Anan'ev, 2000; Vygotskiy, 1997; Pankova, 2015). This study has delineated the field of problems which remained unused for a long time and unresolved in psychology. Different approaches to the psychology of a personal life path are united by a common idea, which is that life plans are understood in general terms as an activity of person (Ralnikova, 2014; Lovpache, 2011). This activity is aimed at the events of the future, but already in the present this activity begins to determine the behavior and activity of a person, leading to the development of person's relations with the surrounding social reality.

Psychological problems of the personal life path are the focus of A. Adler, Sh. Buehler, S. Muddy, A. Maslow, R. May, V. Frankl, Carl Jung and others. Their scientific heritage is for further study, reflection and development of new psychological research about the way of life of the individual and in particular the impact of personal life plans to the behaviour of teenagers who are prone to addictive behaviour.

\section{Problem Statement}

Drawing from classic conceptualizations of values (Rokeach, 1973), the term values describes ab- stract beliefs concerning the perceived importance of various modes of behaviour and finite states. The values are organized into a coherent system of overarching principles that guide attitudes and behaviours (Rokeach, 1973). These values can potentially serve as an internal compass, directing teenagers in the choices they make as they transition into adulthood. Hundreds of papers from many cultures across two decades have confirmed the idea that values can be reduced into 10 basic value types and four higher-order value dimensions (Schwartz et al., 2012). A fundamental assumption of classic value theory is that values are relatively stable, enduring beliefs that should have long-lasting implications for behaviour (Rokeach, 1973). From this perspective, some have argued that values are a key component of identity. With identity development as a key part of teenage years, the future plans and values of teenagers could possibly describe intrapersonal changes during this time.

The various forms of future thinking have been shown to be important for understanding motivation and self-regulation (Lazarenko, 2012). The effect of life plans on the behaviour of teenagers who are prone to addictive behaviour, has not been studied in psychology as a separate issue.

However, the future as a goal of a personal life path has been studied mainly from the perspective of event-driven approach, considering the chronology and content of future events (Golovakha \& Kronik, 2008), the semantic representation of the future in the world view of the person remained out of the research interests up to the present day. The analysis of theoretical and experimental studies allows suggesting that the psychological characteristics and 
principles of time aspects of functioning of the future differ from the semantic ones.

The problem of psychological time in teenage years is important, because in this period, a teenager becomes aware of themselves and their life in time. In our view, it is especially important to study the experience of time in teenagers who are prone to addictive behaviour (Hicks et al., 2012).

An identification of problems that prevent young people from making their plans for the future will help to provide a psychological assistance to these teenagers, which is based on optimizing a personal time perspective (Golovaha \& Kronik, 2014). The addictive behaviour leads to a "change in the motivational, meaningful, and value spheres» of teenager's personality, leading to a distorted perception of time perspectives and deformation in a structure of personal life plans (Lazarenko,2012; Schreiber, 2005). An important characteristic of the relationship to the future is its overall emotional tone, a positive attitude to the future, as well as its realism: the safety related to the future target resources and means to achieve them.

The most productive and developed domestic approach to study of meaning-life orientation of personality is an approach of Leontiev D.A. (2003), who summarized and systematized the existing ideas about the meaning in philosophy and psychology. Leontiev D.A. proposed, that the methodological approach to study of the meaning is based on the unity of three aspects: activity defined by the dynamics of psychological processes of the personal regulation of life activity; phenomenological represented by presentation processes in the world image of the subject of the meanings of significant objects and phenomena; ontology defined by the dynamics of the life relationship of the subject with the world. Leontiev D.A. (2003) developed a semantic concept of the personality detailed in ontological context, in this aspect the semantic reality of a person is achieved due to knowledge of the background and person's relations with it. Personal meaning of time is expressed both in its immediate emotional assessment, and in the degree of cognitive awareness.

\section{Research Questions}

This paper is devoted to studying the impact of the life plans of teenagers on the occurrence of deviant behaviour. We proceeded from the assumption that the structure of personal life plans of teenagers with addictive or non-addictive behaviour would reveal significant difference in terms of the meaning of life and values. Confirmation of this hypothesis may indicate that the psychological characteristics of personal life plans of teenagers affect their addictive behaviour.

In order to confirm or refute this hypothesis, in the study we planned to carry out an experiment on the influence of personal life plans on the behaviour of teenagers with addictive behaviour, and to perform a comparative analysis of life orientations and values of teenagers prone and averse to addictive behaviour.

\section{Purpose of the Study}

The purpose of the study was to investigate the influence of psychological characteristics of personality life plans on the addictive behaviour of teenagers.

The sample included 19 teenagers registered in the juvenile department of the Internal Affairs Directorate №1 in Almaty (experimental group), and 19 pupils of grade 9 of school (control group). The average age of participants was 14 years. The type of addiction of participants of experimental group was drug addiction.

\section{Research Methods}

In order to study the influence of personal life plans on propensity for addictive behaviour in teenagers, an experiment was carried out with a subsequent comparative analysis of meaning-life orientations and values of teenagers, both prone and averse to deviant behaviour that led to addictions. According to the purpose of study the experiment was divided into 2 stages.

1) The psychologist asked participants to complete Kleiberg's test of deviant behaviour, which is a recognised test in Russia, in Kazakhstan. The proposed technique for diagnosing propensity to deviant behaviour is a standardized test questionnaire designed to measure the willingness or propensity of teenagers to the implementation of various forms of deviant behaviour. The questionnaire is a set of psycho diagnostic scales aimed at measuring readiness or propensity to implement certain forms of deviant behaviour. The questionnaire includes two options: female and male. The female version contains 107 questions and 8 scales. The male variant consists of 97 questions and 7 scales, except for the last $8^{\text {th }}$ scale of the female version of the questionnaire «scale of adoption of the female social role». One of the scales of the Kleiberg test is the scale of propensity to addictive behaviour. The method assumes the account and correction of the 
intention for the socially desirable answers of the test subjects. Within the framework of our research, Kleiberg's test of deviant behaviour was used to form a control group of teenagers, which were not prone to deviant or addictive behaviour.

Criteria for the formation of the control group were:

1. Low results in Kleiberg's test of deviant behaviour;

2. The average level of intellectual development;

3. Good results in academic performance.

Initially, we examined 28 participants who were not registered in the Division of Juvenile of the Department of Internal Affairs, finally we formed a control group of 19 pupils.

2) Participants of both groups completed two tests: meaning-life orientations' test (MLO) by Leontiev D.A. (2003), and «Value orientations» test by Rokeach (1973).

Test of meaning-life orientations is an adapted version of «Life goal» test by D. Krambo and L. Macholik. The technique was developed by authors on the basis of the theory of aspiration to the meaning and logotherapyby V. Frankl. The original technique in its final version is a set of 20 scales containing contradictory statements, for example «Life seems to me always exciting and interesting» and «Life seems to me completely boring and routine», measuring the meaningful orientations of the personality. The test person must indicate whether one's position is closer to the first statement, to the second statement or in the middle. The MLO method was developed and adapted by D.A. Leontiev himself. The test considers life meaningful if there are goals, satisfaction when reaching goals and the confidence in one's own ability to set goals, select tasks from available ones and produce results. The important moment is clear comparison of goals with the future, emotional background with the present and the satisfaction with the reached result and the past.

The test of meaning-life orientations (MLO) includes, along with the general indicator of the meaningfulness of life, also five subscales. The components of meaning of life are:

1) Meaning-life orientations - goals in life, the process or interest and emotional intenseness of life, and life productivity or satisfaction by selfrealization;

2) Locus of control - internal locus of control, confidence in the ability to execute control over one's own life (Naurzalina et al., 2015).

The meaning-life orientations themselves 'correlate with the three components of vital function and temporary orientations in life: goal (future), process (present) and the result (past). Goal is 'goals of life' in a certain system of values, the process is the emotional saturation of life and the result is the 'satisfaction with self - actualization' (Leontyev, 2003).

The 'Value orientations' test allows to diagnose features of terminal and instrumental values. M. Rokeach viewed terminal values as beliefs that certain terminal goal of individual life is valued enough to move to it. The examples of terminal values are: comfortable life, prosperity, interesting life, feeling of success, peace in the whole world (cessation of wars and conflicts), world of beauty (beauty of nature and the world of arts), equality (brotherhood, equal opportunity for all), safety of the family (caring for the family), freedom (independence, freedom of choice), happiness (contentment), internal harmony (absence of internal conflicts), public recognition (respect, admiration), true friendship (close friendly relations), wisdom (deep understanding of life) and others. Instrumental values are beliefs that certain way of action or personality feature is preferential in any kind of situation. The examples of terminal values are: ambitiousness (hard work, diligence, dedication), latitude of views (impartiality, perceptivity), abilities (competence, effectiveness), cheerfulness (inspiration), cleanliness (neatness), courage (ready to defend one's position), forgiveness (the ability to forgive others), desire to help (willingness to work for the benefit of others), honesty (sincerity, truthfulness), rich imagination (creativity), independence (selfconfidence, autonomy), mind (intellect, ability to think), logicality (consistency, rationality), love (sensitivity, tenderness), education (courtesy, good manners), responsibility (reliability), self-control (self-discipline, self-restraint) and others. The diagnostics was performed on individual basis.

Thus, M. Rokeach's method was used in the framework of our study for diagnosing the value orientations as criterion of personal life plans: goal values and instrument values.

For the comparative analysis of the results of the MLO test of both groups, we used nonparametric $\mathrm{U}$ test by Mann-Whitney, which is designed for estimation of differences between two independent sample groups simultaneously to compare the obtained results of diagnostics of experimental and control groups of teenagers' meaning-life orientations. In addition, Spearman's correlation coefficient was used to study the impact of personal life plans on the criteria of meaning-life orientations and value orientations on the addictive behavior 
of teenagers. When using Spearman coefficient in the correlation analysis we did not need any presuppositions about the distribution pattern of features in sampled population.

\section{Findings and Discussion}

The results of present study is summarized in Table 1.

Table 1 - Statistical indicators on the scales of meaning-life orientations' method (MLO) by Mann-Whitney

\begin{tabular}{|c|c|c|c|c|c|c|}
\hline $\begin{array}{c}\text { Indicator of } \\
\text { MLO method }\end{array}$ & Goals & Process & Result & $\begin{array}{c}\text { Locus of } \\
\text { control-I }\end{array}$ & $\begin{array}{c}\text { Locus of } \\
\text { control -life }\end{array}$ & $\begin{array}{c}\text { Jverall } \\
\text { meaningfulness } \\
\text { of life }\end{array}$ \\
\hline $\begin{array}{c}\text { Uby Mann- } \\
\text { Whitney }\end{array}$ & 156.0 & 145.0 & 178.0 & 120.5 & 132.0 & 137.5 \\
\hline Significance & 0.47 & 0.30 & 0.94 & 0.05 & 0.16 & 0.21 \\
\hline
\end{tabular}

Statistically significant differences between teenagers of experimental and control groups were revealed only on the subscale of locus of control - I (Table 1). This finding suggests that teenagers in the experimental group do not believe in their abilities to control the events of their lives as much as teenagers in the control group.

The differences between teenagers of experimental and control groups were revealed on the level of descriptive statistics on indicators such as locus of control - I, locus of control - life and overall meaningfulness of life. For teenagers with addictive behaviour it is more typically frustrating to control the events of their lives, compared with teenagers, not prone to addictive behaviour. In comparison with teenagers who are not prone to addictive behaviour, participants with addictive behaviour displayed a tendency to consider human life as something beyond conscious control. In general, the overall meaningfulness of life was higher in the control group. Perhaps this indicates that a low level of formation of life orientations, as a measure of the personal life plans of a teenager, predetermines teenager's tendency to addictive behaviour.

In other scales of meaning-life orientations' test of Leontiev (2003), significant differences in the $\mathrm{U}$ test between teenagers of the experimental and control groups were not found.

The structure of terminal and instrumental values of teenagers in the experimental and control groups was measured by Rokeach test (1973). For terminal values of both experimental and control groups a value block of personal life is significant. One should pay attentionto the fact that the first and third ranks take the values of «health» and «happy family life», respectively. The difference is that the second rank in the hierarchy of value orientations forteenagers with addictive behaviour takes the «existence of good and true friends», and «love» for teenagers in the control group.

A financially secure life is more important for teenagers with addictive behaviours than for teenagers of the control group. Self-confidence, freedom and independence are more important for the control group of teenagers. Life wisdom and development (work on yourself, the constant physical and spiritual perfection) are more significant for teenagers with addictive behaviour than for the control group of teenagers. The last ranks in the hierarchy of value orientations of teenagers of both groups take such values as creativity, purpose, beauty of nature and art.

For teenagers with addictive behaviour, the second rank takes the existence of good and true friends, rather than the value of love as for teenagers in the control group. This may be due, perhaps, to the fact that teenagers with addictive behaviour are part of some informal youth group where relations are based on a specific, often not formal friendship code, but certainly not love. In contrast, the teenagers from the control group, probably, were interested in their first love at that moment more than ina friendship, which corresponds to the characteristics of this age.

The analysis of instrumental values has shown that teenagers of both groups paid great attention to ethical values and values of communication. The value of good manners ranked in first place for both groups' of participants. Neatness, education and honesty are also important to them. At the same time teenagers with addictive behaviour consider the value of education more important than honesty and teenagers in the control group conversely put honesty before education. 
Responsibility and independence are more important for the control group of teenagers than for the experimental group. A significance of cheerfulness is more important for teenagers with addictive behaviour. The value of a business«diligence», is equally important for both groups, but teenagers with addictive behaviour considered that efficiency in business and rationality are more important. The values of communication: courage in defending one's opinion, honesty and advertenceare more important for teenagers of the control group than for teenagers with addictive behaviour. The values of accepting others intransigence to shortcomings in themselves and others and tolerance are preferable for teenagers in the control group than for the experimental group of participants. The analysis of self control subscale in Rokeach' test showed that both groups of participants had similar results.

The instrumental values have a stronger correlation with the meaning-life orientations than the terminal values in experimental group. Perhaps this is due to the fact that these young people, above all, are practice-oriented in their life plans.

The relationship between the index of «purpose in life» and indicators of «interesting work», «high demands» of teenagers with addictive behaviour is statistically significant and positive. The relationship between the index of «purpose in life» and indicators of «freedom», «the happiness of others», «education» and «discipline» in teenagers with addictive behaviour is statistically significant and negative. The results of current study suggests that for teenagers with addictive behaviour a greater number of goals in the future is less significant for them than values such as interesting work and high demands. For participants of experimental group was more important a greater number of goals in the future is than values such as freedom, the happiness of others, good manners and discipline. Perhaps this is due to the fact that a teenager with addiction during formation of future goals, which might give his life meaning, shows certain irrationality.

Freedom and happiness of others as values-goals and good manners and discipline as a values-means play a major role for participants of the experimental group of teenagers who are not able to plan future goals or have difficulties with that. The possible explanation of this result could be a tendency of addictive teenagers to give social desirable answers. So they prefer, to live for others in the future, rather than to pursue their personal values-goals.
The relationship between the index of «the effectiveness of life» and indicators «efficiency in the affairs» and «high demands» of teenagers with addictive behaviour is statistically significant and positive. The relationship between the index of «the effectiveness of life» and an indicator of "good manners» in teenagers with addictive behaviour is statistically significant and negative. Perhaps this result is explained by the fact that a teenager with addictive behaviour, if not satisfied with their selfrealization, then lowers them self to the level of the personal unconscious claims without presenting them self to the highest requirements and assessing its efficiency or inefficiency in business. Thus it solves the problem of self-realization satisfaction by reducing their personal aspirations. If a teenager with addictive behaviour has a high level of satisfaction with their self-realization, then they are able to appreciate such value-mean as «good manners».

The relationship between the index of «locus of control-I» and indicators «efficiency in the affairs», «high demands» of teenagers with addictive behaviour is statistically significant and positive. It means that social support, strong and good relationships with friends help them to deal with internal locus control and control of their own behaviour. Perhaps this result is explained by the fact that participants with addictive behaviour, if they do not feel strong, free personality, unconsciously begin to lower evaluate the «efficiency in the affairs» and «high demands», as they do not believe in their ability to control the events of their lives. If a teenager with addictive behaviour considers them self as a strong personality, able to build their life in accordance with their objectives, so they are able at the same time to appreciate such value-means as «good manners». Otherwise, the value of «good manners» is not important for this teenager.

The relationship between the indexes of «locus of control - life» and «the existence of good and faithful friends», «high demands», «openmindedness» indicators of teenagers with addictive behaviour is statistically significant and positive. The relationship between the index of «locus of control - life» and an indicator of «good manners» in teenagers with addictive behaviour is statistically significant and negative. The results of the current study explain the fact that teenagers with addictive behaviour tend to think that they are unable to control their life, so participants of the experimental group unconsciously underestimate values such as the availability of good and loyal friends, high demands, open-mindedness, because, they often 
just believe in destiny, in some fatal coincidence. If a teenager with addictive behaviour considers it possible to freely make decisions and implement them, they are able to appreciate at the same time such value-means as «good manners». Otherwise, the value of «good manners» is not important for them.

The positive correlations between general indicator of «life meaningfulness» and an indicator of «high demands» in teenagers with addictive behaviour are statistically significant and positive. The relationship between the indicator «overall meaningfulness of life» and the indication of «good manners» in teenagers with addictive behaviour is statistically significant and negative. Those findings suggest that «meaning life orientations» could positively affect teenager behaviour, improve their «good manners» and help to make a good impression on their surroundings, which are very important for teenagers with addiction.

Between the various indicators of personal life plans in teenagers not prone to addictive behaviours were also identified structural relationships. The relationship between the index of «purpose in life» and the indication of «discipline» in teenagers in the control group was statistically significant and positive. The relationship between the index of «purpose in life» and the indication of «strong will» in teenagers is statistically significant and negative. The results of study show that for participants of control group quantity of goals in the future is less significant than «discipline» value. The increasing number of future plans influence on «strong will» - the ability to take something to an end, rather than discipline, which sometimes prevents some flexibility in achieving goals.

The relationship between the indicator «life process» and the indication of «interesting work» in the control group of teenagers is statistically significant and positive. The relationship between the indicator «life process» and indicators of «freedom» and «strong will» in teenagers is statistically significant and negative. The analysis of study suggests that the more emotionally intense is the life of a teenager, the less significant for them is the value of interesting work. According to this point the more emotionally saturated the life of a teenager is, the more important to them are such values like freedom and a strong will. The more the teenager lives an emotionally rich life, the more they appreciate strong will, which gives them the opportunity to enjoy life on the basis of their interests, while not ignoring the interests of others. Interesting work as a value-goal may be considered by a teenager as narrowing the scope of an eventful life and prevention factor of addictive behaviour.

The relationship between the index of «the effectiveness of life» indicators and «freedom» and «strong will» in teenagers is statistically significant and negative. The results suggest that the greater the satisfaction of self-realization in the teenager, the more important are values such as freedom for them and a strong will.

The relationship between the index of «locus of control-I» and the indication of «the happiness of others» among teenagers in the control group was statistically significant and positive. The relationship between the index of «locus of control-I» and indicators «education», «responsibility» and «strong will» in teenagers is statistically significant and negative. This revealed directly positive correlation suggests that the more pronounced the locus of control-I a teenager has, the less significant for them are such values as the happiness of others, and vice versa. The resulting inverse relationship suggests that the more pronounced the locus of control-I a teenager has, the more important for them are such values as education, responsibility, strong will, and vice versa. Perhaps this result is explained by the fact that a teenagers, considering themselves to have a strong, free personality, is not always willing to be guided by others, which is characteristic of this age. Locus of control-I has been associated with teenagers, who are not prone to addictive behaviours, with the value of education, responsibility and a strong will.

The relationship between the index of «locus of control - life» and the indicator «interesting work» in the control group of teenagers was statistically significant and positive. The resulting directly proportional relationship suggests that the more pronounced is locus of control - life in teenagers without addictive behaviour, the less significant for them is such a value as interesting work, and vice versa. Perhaps this result is explained by the fact that a teenager growing up in today's economic environment, unconsciously does not want to reduce the scope of their vitality only for employment in the workplace.

The relationship between the indicator «overall meaningfulness of life» and indicators of «interesting work», «sensitive» in teenagers of the control group was statistically significant and positive. The relationship between the indicator «overall meaningfulness of life» and indicators 
of «freedom», «responsibility», «strong will» in teenagers is statistically significant and negative. Perhaps an interesting job, and sensitive as valuesmeans and value-goals do not meet modern representations of a teenager, so to treat them as values is reduced. As is shown in our study, a teenager does not always understand what lies behind the concept of «interesting work», as the work can be interesting, but poorly paid, it is possible to prevent young people from appreciating this value. «Strong will» as a value-mean is a central point in meaning-life orientations and values of a teenager, not prone to addictive behaviour. The value-mean «responsibility» is in second place.

\section{Conclusion}

Overall, this study shows that there are significant differences both in individual indicators, and on the relationships between the meaning-life orientations and value orientations in the structure of personal life plans of teenagers with addictive behaviour and teenagers, not prone to addiction. This result may indicate that the psychological aspects of personal life plans for teenagers influence the development of addictive behaviours. Values are often, but not always, related to corresponding behaviours, and often values predict behaviours theorized to be expressive of other values. Maturity of personal life plans of teenagers as a factor of the risk of addictive behaviour is important to consider for effective prevention and psycho-correctional work with teenagers. Identified characteristics of personal life plans of an addictive teen can be used in psycho-diagnostic purposes in a comprehensive forensic psychological and psychiatric examination or forensic psychiatric examination, which will enable more informed and reasonably given expert advice and predict the risk of relapse of addictive behaviours.

\section{Литература}

Gilbert, D.T., Wilson, T.D. Prospection: experiencing the future. // Science. - 2007. - № 317(5843). - C.1351-1354.

Hicks J. A., Trent J., Davis W. E., King L. A. Positive affect, meaning in life, and future time perspective: An application of socioemotional selectivity theory // Psychology and Aging. - 2012. - № 27 (1). C. 181-189.

Lovpache, F.G. Life prospects as the main indicator of personality development in teenage years // Bulletin of Adygeya State University. - 2011. - № 3(3). - C. 179-184.

Peetsma T., Van der Veen I. Relations between the development of future time perspective in three life domains, investment in learning, and academic achievement // Learning and Instruction. - 2011. - № 21. - C. 481-494.

Rokeach, M. The nature of human values. - New York: Free Press, 1973

Seligman, M., Railton, P., Baumeister, R.F., Sripada, C. Navigating into the future or driven by the past // Perspectives on Psychological Science. - 2013. - № 8(2). - C. 119-141

Ананьев Б.Г. Человек как предмет знаний. - СПб.: Питер, 2000.

Ахмеров Р.А. Субъективная картина жизненного пути в структуре сознания // В мире научных открытий. - 2013. - № 3 (43). C. 190-220.

Выготский Л.С. Собрание сочинений Том 3: Проблемы теории и истории психологии. / Перевод с введением Р. ван дер Веера. - Редакция Р. В. Рибер и Дж. Уоллок. - Нью-Йорк: Пленум Пресс, 1997.

Головаха Е.И., Кроник А.А. Понятие психологического времени и принципы конструктивной психологии (от интроспективной реконструкции к конструированию знаний) // ПЕМ: Психология. Educology. Медицина. - 2014. - С. 1112115.

Кроник А.А., Ахмеров Р.А. Психогенология: история становления, первые эксперименты и перспективы развития // ПЕМ: Психология. Educology. Медицина. - 2015. - № 3 (4). - С. 30-52.

Лазаренко Д.В. Анализ подходов к изучению аддиктивного поведения в современной психологии // Труды Института гуманитарных наук Тбилисского государственного университета. - 2012. - № 2 (13). - С. 62-64.

Леонтьев Д. А. Значение психологии. - М.: Смысл, 2003. - 488 с.

Наурзалина Д., Толегенова А., Карабалина А., Альмурзаева Б., Бакиева С., Садыкова Н. Влияние эмоционального интеллекта на формирование смысло-экзистенциальной стратегии среди студентов // Процедия - Социальные и поведенческие науки. - 2015. - № 171. - С. 390-395.

Панкова А.А. Теоретико-методологические основы исследования проблемы жизненной перспективы в отечественной и зарубежной психологии и педагогике // Наука и образование сегодня. - 2015. - № 1 (12). - С. 74-77.

Ральникова Р.А. Временные проблемы в психологии: транссексуальный анализ (перевод: Временные проблемы в психологии: трансспектативный анализ) // Известия Алтайского государственного университета. - 2014. - № 2 (82). - С. 6166.

Ральникова Р.А., Гурова О.С., Ипполитова Е.А. Жизненные перспективы личности: риск воспроизводства девиантного поведения. - Барнаул, 2012. 
Шварц С.Х., Сичюх Дж., Веччионе М., Давыдов Е., Фишер Р., Бейерлейн С., Конти М. Уточнение теории базовых индивидуальных ценностей // Журнал личности и социальной психологии. - 2012. - № 103 (4). - С. $663-688$.

Шрайбер Т. В. Проблема регуляции смыслотворческой деятельности в раннем юношеском возрасте. Основы и перспективы психологической науки и практики в российском обществе: материалы российской научно-практической конференции. - Набережные Челны: Изд-во Института управления, 2005. - С. 80-83.

\section{References}

Ahmerov, R.A. (2013). Subektivnaya kartina zhiznennogo puti v structure soznaniya. V mire nauchnyh otkritiy [Subjective picture of life's journey in the consciousness structure. In the world of scientific discoveries], No. 7.3(43), pp. 190-220.

Anan'ev, B.G. (2000). Chelovek kak predmet znaniy [Human as knowledge subject]. Spb., Piter.

Gilbert, D.T., Wilson, T.D. (2007). Prospection: experiencing the future. Science, No. 317(5843), pp. 1351-1354.

Golovakha E.I., Kronik, A.A. (2014). Ponyatie psihologicheskogo vremeni I principy konstruktivnoi psihologii (ot introspektivnoi rekonstrukcii k konstruirovaniyu znanii) [The concept of psychological time and the principles of constructive psychology (from introspective reconstruction to constructing knowledge)]. PEM: Psychology. Educology. Medicine, No 1, pp.112-115.

Hicks, J. A., Trent, J., Davis, W. E., King, L. A. (2012). Positive affect, meaning in life, and future time perspective: An application of socioemotional selectivity theory. Psychology and Aging, No 27 (1), pp. 181-189

Kronik, A.A., Ahmerov, R.A. (2015). Psichogenologiya: istoriya stanovleniya, pervyie experimenty I perspektivy razvitiya [Psychogenology: the history of formation, the first experiments and development prospects]. PEM: Psychology. Educology. Medicine, No. 3(4), pp. 30-52.

Lazarenko, D.V. (2012). Analyz podhodov k izucheniyu addiktivnogo povedeniya v sovremennoi psichologiyi [The analysis of approaches to the study of addictive behaviours in modern psychology]. Proceedings of the Institute of Humanities of Tbilisi State University, No. 2(13), pp. 62-64.

Leontiev, D. A. (2003). Meaning psychology. Moscow: Smysl, 488 p.

Lovpache, F.G. (2011). Life prospects as the main indicator of personality development in teenage years // Bulletin of Adygeya State University, No. 3(3), pp. 179-184.

Naurzalina, D., Tolegenova, A., Karabalina, A., Almurzayeva, B., Bakiyeva, S., Sadykova, N. (2015). Vliyanie emocionalnogo intellekta na formirovaniye smislo-ekzistencialnoi strategii sredi studentov [Impact of Emotional Intelligence on Formation of Meaning-existential Strategy among Students]. Procedia - Social and Behavioral Sciences, No. 171, pp. 390-395.

Pankova, A.A.(2015). Teoretiko-metodologicheskiye osnovy issledovaniya problemy zhiznennoi perspektivy v otechestvennoi I zarubejnoi psichologiyi I pedagigike [Theory and methodological bases of research of a problem of the vital prospect in domestic and foreign psychology and pedagogic]. Science and Formation today, No. 1 (12), pp. 74-77.

Peetsma, T., Van der Veen, I. (2011) Relations between the development of future time perspective in three life domains, investment in learning, and academic achievement. Learning and Instruction, No. 21, pp. 481-494.

Ralnikova, R.A., Gurova, O.S., Ippolitova, E.A. (2012). Zhiznenniye perspektivy lichnosti: risk vosproizvodstva deviantnogo povedeniya [Life perspectives of the personality: the risk of reproduction of deviant behaviour]. Barnaul.

Ralnikova, R.A. (2014). Vremenniye problemy v psichologii: transeksualnii analiz [Temporary problems in psychology: transsexual analysis (translation: Temporal Problems in Psychology: Transspective Analysis)] .Izvestiya Altai State University, No. 2-2 (82), pp. 61-66.

Rokeach, M. (1973). The nature of human values. New York: Free Press.

Seligman, M., Railton, P., Baumeister, R.F., Sripada, C. (2013) Navigating into the future or driven by the past.Perspectives on Psychological Science. 8(2),119-141

Schreiber, T. V. (2005).Problema regulyacii smyslotvorcheskoi deyatelnosti v rannem yunosheskom vozraste. Osnovy I perspektivy psichologicheskoi nauki I praktiki v rossiisko, obshestve [Problem of regulation of the meaning-making activity in the early juvenile age. Fundamentals and perspectives of the psychological science and practice in the Russian society: materials of the Russian scientific and practical conference] Naberezhniye Chelny: Edition of the Management Institute, pp. 80-83.

Schwartz, S.H., Cieciuch, J., Vecchione, M., Davidov, E., Fischer, R., Beierlein, C., Konty, M. (2012) Refining the theory of basic individual values. Journal of Personality and Social Psychology, 103(4), pp. 663-688.

Vygotsky, L.S. (1997) Sobraniye sochineniy T. 3. Problemy teorii I istorii psichologii [The Collected Works of L.S. Vygotsky. Volume 3: Problems of the Theory and History of Psychology]. Translated and with an Introduction by R. van der Veer. Editors R.W. Rieber \& J. Wollock. New York, Plenum Press 